\title{
Research on Talent Training Mode of Interdisciplinary Integration in Colleges and Universities
}

\author{
Xiaomei Hu*, Fan Liu, Yuan Yuan \\ School of Management Science and Engineering, Anhui University of Finance and Economics, Bengbu, Anhui, 233030, China \\ *Corresponding author email: huxiaomeimei@126.com
}

\begin{abstract}
Interdisciplinary and integrated talent training is not only the urgent need of economic, scientific, technological and social development, but also one of the inevitable trends of higher education and teaching reform. Firstly, this paper analyzes and summarizes three types of multidisciplinary talent training modes in American universities, namely, project-based interdisciplinary talent training mode, professional education based interdisciplinary talent training mode and curriculum based interdisciplinary talent training mode. Then, it compares and analyzes four modes of interdisciplinary talent training in Colleges and universities in China, namely interdisciplinary curriculum mode, interdisciplinary project mode, interdisciplinary specialty mode and interdisciplinary degree mode. Finally, it puts forward the design idea of curriculum system of interdisciplinary and integrated talent training mode in China.
\end{abstract}

Keywords: Interdisciplinary integration, Talent training mode, Curriculum system.

\section{Interdisciplinary Integration Theory}

Interdisciplinary and integrated talent training is not only the urgent need of economic, scientific and technological and social development, but also one of the inevitable trends of higher education and teaching reform. Its implementation results may produce new academic fields. Therefore, it is an important way for colleges and universities to make academic innovation and obtain major innovative results.

Interdisciplinary integration usually refers to two or more disciplines, based on the needs of existing or future technology and industrial development, to achieve cross penetration, interaction and combination through theoretical infiltration, object integration, concept transplantation, technology complementarity and function integration, so as to construct a new comprehensive discipline system across a single discipline, which is the key for colleges and universities to improve their core competitiveness An important strategy for cultivating emerging disciplines [1]. Interdisciplinary integration talent training does not deny discipline differences, but based on discipline differences, constantly break the boundaries of various disciplines and promote mutual cross penetration. According to the discipline development law, when extended to a certain degree of depth and breadth, the development of a discipline will have a bottleneck, which requires the help of other related disciplines, the integration of useful technologies and methods, the discovery of new breakthroughs and the formation of new disciplines. Interdisciplinary integration needs to break the barriers between traditional disciplines, break through the obstacles of professional training, build the foundation and atmosphere of discipline integration, find the meeting point of cross integration through the related factors between disciplines, integrate relevant elements, focus on the development needs of future technology and industry, and deal with the relatively uncertain dynamic changing environment, Create an innovative effect with interdisciplinary integration [2].

The research on interdisciplinary integration abroad began in 1960. Many universities such as Harvard University,
Oxford University, Stanford University and the University of Tokyo have successively established different types of interdisciplinary research groups and platforms to cooperate in the research of multiple disciplines such as medicine, biology, physics, computing machine and materials, so as to promote the interdisciplinary integration. For example, in 2006, Oxford University established the E-research interdisciplinary cooperation center, which is committed to connecting the exchange, learning and research between domestic and international universities, providing various solutions for other disciplines through its own computer professional advantages, and realizing the combined research in many fields such as science, humanities, social sciences, technology and information infrastructure. The interdisciplinary research in China is slightly later than that in western countries. It began around the end of 1980s and mainly focuses on the fields of medicine, bioengineering, environment, management science and so on. Since the $21 \mathrm{st}$ century, interdisciplinary integration research has gradually attracted the attention of domestic university research institutes and achieved rapid development. Peking University, Tsinghua University, Fudan University, Shanghai Jiaotong University and the Chinese Academy of sciences have established interdisciplinary research centers, which has built a broad platform for relevant research. For example, in 2006, Peking University established a frontier Interdisciplinary Research Institute, mainly involving mathematics, biology, chemistry and other disciplines, which was approved by the Ministry of education. The Institute independently established three new interdisciplinary secondary disciplines, namely "nanotechnology", "data science" and "integrated life science". It can be seen that by building a research platform for interdisciplinary integration, colleges and universities promote interdisciplinary innovation research, achieve major breakthroughs in the forefront of science and technology, and further promote the development of interdisciplinary integration [3]. 


\section{The Main Mode of Interdisciplinary Talent Training in the United States}

In the 21st century, the acceleration of global economic integration and the rapid development of science and technology provide an opportunity for teaching reform for colleges and universities to cultivate compound talents with multi-disciplinary knowledge and ability. At the same time, the increasing importance of interdisciplinary research promotes the maturity of interdisciplinary and integrated talent training all over the world. Foreign universities began to explore interdisciplinary talent training very early. Longterm practice has brought fruitful development results and accumulated a lot of experience, especially in American universities. Many famous American universities have set up interdisciplinary courses, interdisciplinary degree programs and interdisciplinary research programs. Their interdisciplinary talent training ideas and methods are worthy of reference for domestic universities. By reading a large number of relevant literature, it is analyzed and summarized that the multidisciplinary talent training mode of American universities is mainly divided into three categories: Projectbased interdisciplinary talent training mode, professional education based interdisciplinary talent training mode and curriculum based interdisciplinary talent training mode [4]. This paper compares and analyzes the three types of models from the connotation, form and implementation path of talent training model, supplemented by case description. The comparison of the main modes of interdisciplinary talent training in American universities is shown in Table 1.

Table 1. Comparison of main modes of interdisciplinary talent training in American Universities

\begin{tabular}{|c|c|c|c|c|c|c|}
\hline Type & $\begin{array}{l}\text { Implementation } \\
\text { approach }\end{array}$ & Main features & Advantage & Inferiority & $\begin{array}{c}\text { Scope of } \\
\text { application }\end{array}$ & Classic case \\
\hline $\begin{array}{l}\text { Project based } \\
\text { interdisciplinary } \\
\text { talent training } \\
\text { model }\end{array}$ & $\begin{array}{c}\text { Set up } \\
\text { interdisciplinary } \\
\text { degree projects; (2) } \\
\text { Interdisciplinary } \\
\text { research projects } \\
\text { participated by } \\
\text { students. }\end{array}$ & $\begin{array}{c}\text { (1) } \\
\text { Interdisciplinary } \\
\text { integration is } \\
\text { substantive; (2) } \\
\text { Strong } \\
\text { application, } \\
\text { focusing on } \\
\text { cultivating } \\
\text { interdisciplinary } \\
\text { practical ability; } \\
\text { (3) } \\
\text { Institutionalization } \\
\text { and } \\
\text { systematization, } \\
\text { relying on a } \\
\text { discipline or } \\
\text { institution. }\end{array}$ & $\begin{array}{l}\text { Cultivate } \\
\text { talents who } \\
\text { can quickly } \\
\text { adapt to the } \\
\text { future } \\
\text { scientific } \\
\text { field and } \\
\text { social } \\
\text { development } \\
\text { and changes, } \\
\text { and have } \\
\text { sufficient } \\
\text { potential for } \\
\text { development. }\end{array}$ & $\begin{array}{l}\text { (1) The existing } \\
\text { organizational } \\
\text { structure and } \\
\text { management } \\
\text { system are easy to } \\
\text { form constraints; } \\
\text { (2) Limited by the } \\
\text { national degree } \\
\text { system; (3)The } \\
\text { construction cycle } \\
\text { of degree projects } \\
\text { is long; (4) More } \\
\text { people, materials } \\
\text { and financial } \\
\text { resources are } \\
\text { invested. }\end{array}$ & $\begin{array}{l}\text { It is applicable } \\
\text { to schools with } \\
\text { strong } \\
\text { interdisciplinary } \\
\text { awareness, } \\
\text { certain } \\
\text { scientific } \\
\text { research and } \\
\text { teaching } \\
\text { foundation and } \\
\text { strong strength. }\end{array}$ & $\begin{array}{c}\text { Interdisciplinary } \\
\text { bachelor } \\
\text { program of } \\
\text { Carnegie } \\
\text { Mellon } \\
\text { University, joint } \\
\text { program of MIT } \\
\text { and Woods } \\
\text { Hole Institute of } \\
\text { Oceanography. }\end{array}$ \\
\hline $\begin{array}{l}\text { Interdisciplinary } \\
\text { talent training } \\
\text { model based on } \\
\text { Professional } \\
\text { Education }\end{array}$ & $\begin{array}{l}\text { (1) General and } \\
\text { professional } \\
\text { courses; } \\
\text { (2)Interdisciplinary } \\
\text { enrollment; (3) } \\
\text { Interdisciplinary } \\
\text { research carried } \\
\text { out by individual } \\
\text { students.. }\end{array}$ & $\begin{array}{l}\text { (1) Strong } \\
\text { operability; } \\
\text { (2) Conform to the } \\
\text { construction } \\
\text { principle of the } \\
\text { original } \\
\text { professional } \\
\text { education } \\
\text { structure. }\end{array}$ & $\begin{array}{l}\text { It has no } \\
\text { impact on the } \\
\text { existing } \\
\text { discipline } \\
\text { system and } \\
\text { the } \\
\text { organizational } \\
\text { structure of } \\
\text { colleges and } \\
\text { departments, } \\
\text { and is easy to } \\
\text { implement. }\end{array}$ & $\begin{array}{l}\text { (1) No systematic } \\
\text { interdisciplinary } \\
\text { activities have } \\
\text { been formed; (2) } \\
\text { More dependent } \\
\text { on students' } \\
\text { individual interest } \\
\text { and ability in } \\
\text { interdisciplinary } \\
\text { learning. }\end{array}$ & $\begin{array}{l}\text { Applicable to } \\
\text { all schools, } \\
\text { disciplines and } \\
\text { majors. }\end{array}$ & $\begin{array}{c}\text { Economics at } \\
\text { MIT and law at } \\
\text { Duke } \\
\text { University. }\end{array}$ \\
\hline $\begin{array}{l}\text { Interdisciplinary } \\
\text { talent training } \\
\text { model based on } \\
\text { Curriculum }\end{array}$ & $\begin{array}{l}\text { (1) "Unconscious" } \\
\text { curriculum and } \\
\text { teaching.(2) } \\
\text { Interdisciplinary } \\
\text { elective courses; } \\
\text { (3) Consciously set } \\
\text { up } \\
\text { interdisciplinary } \\
\text { courses. }\end{array}$ & $\begin{array}{l}\text { (1) Diversified } \\
\text { curriculum } \\
\text { knowledge; (2) } \\
\text { Courses with } \\
\text { inclusive, one- } \\
\text { time and open } \\
\text { characteristics.(3) } \\
\text { Attach importance } \\
\text { to the integration } \\
\text { of resources. }\end{array}$ & $\begin{array}{l}\text { It is easy to } \\
\text { implement } \\
\text { and avoid the } \\
\text { constraints of } \\
\text { traditional } \\
\text { discipline } \\
\text { system. }\end{array}$ & $\begin{array}{l}\text { (1) Non } \\
\text { systematic; }(2) \\
\text { There are high } \\
\text { requirements for } \\
\text { teachers' design } \\
\text { level and team } \\
\text { cooperation } \\
\text { willingness; } \\
\text { (3)The identity of } \\
\text { interdisciplinary } \\
\text { teaching teachers } \\
\text { is difficult to be } \\
\text { recognized from } \\
\text { management and } \\
\text { system. }\end{array}$ & $\begin{array}{l}\text { It is applicable } \\
\text { to schools, } \\
\text { studies and } \\
\text { disciplines with } \\
\text { interdisciplinary } \\
\text { foundation and } \\
\text { research } \\
\text { intention. }\end{array}$ & $\begin{array}{c}\text { "Climate } \\
\text { change and the } \\
\text { future of } \\
\text { California" } \\
\text { course at the } \\
\text { University of } \\
\text { California, } \\
\text { Berkeley, } \\
\text { energy and } \\
\text { environment } \\
\text { Certificate } \\
\text { Course at Duke } \\
\text { University, etc. }\end{array}$ \\
\hline
\end{tabular}

As can be seen from table 1, the curriculum based training mode is the primary and basic one of the three modes, while the other two modes, especially the project-based training mode, take the curriculum as an implementation way.
Therefore, the curriculum can be regarded as the cornerstone of interdisciplinary talent training. In terms of interdisciplinary talent training, China's colleges and universities should start with the setting and development of 
interdisciplinary integration curriculum.

\section{The Main Mode of Interdisciplinary Talent Training in China}

In recent years, interdisciplinary talent training has been paid more and more attention in Colleges and universities in
China, and some colleges and universities have begun to study related aspects. At present, there are mainly four interdisciplinary talent training modes in Colleges and universities in China, namely interdisciplinary curriculum mode, interdisciplinary project mode, interdisciplinary specialty mode and interdisciplinary degree mode [5].

Table 2. Comparison of main training modes of interdisciplinary talents in Chinese Universities

\begin{tabular}{|c|c|c|c|c|c|c|}
\hline Type & $\begin{array}{l}\text { Implementation } \\
\text { approach }\end{array}$ & Main features & Advantage & Inferiority & $\begin{array}{c}\text { Scope of } \\
\text { application }\end{array}$ & Classic case \\
\hline $\begin{array}{l}\text { Interdisciplinary } \\
\text { curriculum } \\
\text { model }\end{array}$ & $\begin{array}{l}\text { (1) Open hidden } \\
\text { courses } \\
\text { involving multi- } \\
\text { disciplinary } \\
\text { contents; (2) } \\
\text { Establish an } \\
\text { interdisciplinary } \\
\text { elective system; } \\
\text { (3) Consciously } \\
\text { establish } \\
\text { interdisciplinary } \\
\text { courses. }\end{array}$ & $\begin{array}{c}\text { (1) Basic and } \\
\text { diversified } \\
\text { curriculum } \\
\text { knowledge; (2) } \\
\text { Strong operability; } \\
\text { (3) Non systematic. }\end{array}$ & $\begin{array}{l}\text { Avoid conflict } \\
\text { with traditional } \\
\text { discipline } \\
\text { system. }\end{array}$ & $\begin{array}{l}\text { (1) The learning } \\
\text { system is not } \\
\text { strong; (2) The } \\
\text { quality of students } \\
\text { and teachers is } \\
\text { required to be } \\
\text { high; (3) The } \\
\text { identity of } \\
\text { students and } \\
\text { teachers is lack of } \\
\text { institutional } \\
\text { guarantee. }\end{array}$ & $\begin{array}{l}\text { It is basically } \\
\text { applicable to all } \\
\text { schools, } \\
\text { disciplines and } \\
\text { majors. }\end{array}$ & $\begin{array}{l}\text { "Three three } \\
\text { system" } \\
\text { course of } \\
\text { Nanjing } \\
\text { University. }\end{array}$ \\
\hline $\begin{array}{l}\text { Interdisciplinary } \\
\text { project model }\end{array}$ & $\begin{array}{l}\text { Take the lead in } \\
\text { major projects, } \\
\text { teachers and } \\
\text { students from } \\
\text { different } \\
\text { departments and } \\
\text { disciplines } \\
\text { participate } \\
\text { together, and } \\
\text { use } \\
\text { interdisciplinary } \\
\text { knowledge to } \\
\text { solve project } \\
\text { problems. }\end{array}$ & $\begin{array}{l}\text { (1) It is applicable, } \\
\text { flexible and } \\
\text { unsustainable. (2) } \\
\text { Interdisciplinary is } \\
\text { substantive. }\end{array}$ & $\begin{array}{l}\text { The training } \\
\text { program, } \\
\text { scientific } \\
\text { research } \\
\text { training and } \\
\text { curriculum are } \\
\text { flexible, the } \\
\text { operation } \\
\text { organization } \\
\text { carrier is virtual, } \\
\text { and is not } \\
\text { constrained by } \\
\text { the traditional } \\
\text { discipline } \\
\text { system. }\end{array}$ & $\begin{array}{c}\text { Over reliance on } \\
\text { project support } \\
\text { makes } \\
\text { interdisciplinary } \\
\text { talent training } \\
\text { uncertain and } \\
\text { research projects } \\
\text { unsustainable. }\end{array}$ & $\begin{array}{l}\text { It is applicable } \\
\text { to schools with } \\
\text { a certain } \\
\text { interdisciplinary } \\
\text { research and } \\
\text { teaching } \\
\text { foundation and } \\
\text { strong strength. }\end{array}$ & $\begin{array}{l}\text { "Undergradua } \\
\text { te resident } \\
\text { research } \\
\text { project" of } \\
\text { Nanjing } \\
\text { University. }\end{array}$ \\
\hline $\begin{array}{l}\text { Interdisciplinary } \\
\text { professional } \\
\text { model }\end{array}$ & $\begin{array}{l}\text { (1) Set up a } \\
\text { new, all-round } \\
\text { and forward- } \\
\text { looking } \\
\text { education and } \\
\text { teaching reform } \\
\text { plan; (2) Set up } \\
\text { interdisciplinary } \\
\text { majors. }\end{array}$ & $\begin{array}{l}\qquad(1) \\
\text { Institutionalization; } \\
\text { (2) Systematization. }\end{array}$ & $\begin{array}{l}\text { (1) The } \\
\text { implementation } \\
\text { of the system is } \\
\text { guaranteed; (2) } \\
\text { Interdisciplinary } \\
\text { knowledge } \\
\text { learning is } \\
\text { conducive to } \\
\text { promoting the } \\
\text { formation of } \\
\text { substantive } \\
\text { cross } \\
\text { integration. }\end{array}$ & $\begin{array}{c}\text { (1) Large } \\
\text { investment in } \\
\text { human, material } \\
\text { and financial } \\
\text { resources; (2) The } \\
\text { school is required } \\
\text { to have strong } \\
\text { interdisciplinary } \\
\text { willingness and } \\
\text { strong } \\
\text { comprehensive } \\
\text { strength. }\end{array}$ & $\begin{array}{l}\text { It is suitable for } \\
\text { schools with } \\
\text { high degree of } \\
\text { internationalizat } \\
\text { ion, strong } \\
\text { comprehensive } \\
\text { strength and } \\
\text { great spirit of } \\
\text { reform and } \\
\text { innovation. }\end{array}$ & $\begin{array}{l}\text { Yuanpei } \\
\text { College of } \\
\text { Peking } \\
\text { University }\end{array}$ \\
\hline $\begin{array}{l}\text { Interdisciplinary } \\
\text { degree model }\end{array}$ & $\begin{array}{l}\text { (1) Set up } \\
\text { within the } \\
\text { school; (2) } \\
\text { Cooperation } \\
\text { between } \\
\text { schools, } \\
\text { including } \\
\text { transnational } \\
\text { double degree } \\
\text { projects. }\end{array}$ & $\begin{array}{c}\text { (1) Forward } \\
\text { looking; (2) } \\
\text { internationalization. }\end{array}$ & $\begin{array}{c}\text { (1) Promote } \\
\text { domestic } \\
\text { universities to } \\
\text { share resources, } \\
\text { cooperate and } \\
\text { exchange; (2) } \\
\text { Learn from the } \\
\text { experience of } \\
\text { foreign first- } \\
\text { class } \\
\text { universities. }\end{array}$ & $\begin{array}{l}\text { (1) It is not } \\
\text { conducive to the } \\
\text { development of } \\
\text { double degree } \\
\text { education; (2) It is } \\
\text { limited by the } \\
\text { national degree } \\
\text { system. }\end{array}$ & $\begin{array}{l}\text { It is suitable for } \\
\text { schools with } \\
\text { high degree of } \\
\text { internationalizat } \\
\text { ion, strong } \\
\text { comprehensive } \\
\text { strength and } \\
\text { oriented to } \\
\text { social needs. }\end{array}$ & $\begin{array}{c}\text { Tsinghua } \\
\text { University } \\
\text { minor and } \\
\text { double degree } \\
\text { undergraduate } \\
\text { education. }\end{array}$ \\
\hline
\end{tabular}

It can be seen from table 2 that the interdisciplinary degree of the curriculum model is the lowest, and the interdisciplinary degree model is the highest. The common point of developing interdisciplinary education in Colleges and universities in China and the United States is that they both pay high attention to interdisciplinary education and realize its important role in social and economic development and excellent talent training. Colleges and universities actively explore the development of interdisciplinary education and integrate it into talent training education to cultivate compound and applied high-quality talents with interdisciplinary thinking. China's interdisciplinary talent 
training system has not yet developed mature. The existing interdisciplinary degree model has only two degrees, which is essentially different from the American interdisciplinary degree model. However, following the law of things' development, the development degree of interdisciplinary talent training in Colleges and universities in China will gradually improve. When developing interdisciplinary and integrated talent training, domestic colleges and universities should follow the development law of interdisciplinary and integrated education, select the appropriate interdisciplinary and integrated talent training mode in combination with their own comprehensive strength, and gradually improve the degree of interdisciplinary and integrated development with the deepening of the development stage.

\section{Curriculum System Design of Interdisciplinary and Integrated Talent Training Mode in China}

Talent training plan is the overall plan and implementation plan for the school to achieve talent training objectives and basic requirements. The talent training scheme design based on interdisciplinary is a systematic design of training objectives, training contents and training approaches, involving the integrated treatment of many relationships between disciplines and majors, courses and teaching, management and evaluation. How to form an interdisciplinary talent training theory and mechanism with international vision and suitable for local conditions is not only the refinement and activation of talent training mode, but also the direction and content of interdisciplinary talent training teaching reform. Curriculum reform and construction is the core and foothold of talent training mode. This is determined by the basic nature of universities, the characteristics of innovative talents and growth factors. University curriculum is the result of organizing and processing knowledge according to the needs of education. It involves the understanding and selection of knowledge, the understanding and implementation of education, the views on the roles and roles of students and teachers, the interpretation of school functions, the treatment of the relationship between education and society, individuals and disciplines, and so on. Different from the traditional subject centered curriculum, in a sense, the development and construction of "Curriculum" based on interdisciplinary is undoubtedly an all-round transformation and integrated design of the curriculum system of traditional branch universities, and an inevitable path to cultivate interdisciplinary talents.

\subsection{Curriculum Organization: From "Discipline Logic" to "Problem Logic"}

How should interdisciplinary cross integration courses be organized, designed, and organized together with related discipline knowledge to form a new curriculum organization? The traditional curriculum organizes the content according to the structure and characteristics of the discipline. Typical course types and organizational structures include: subject courses and experience courses, subject courses and comprehensive courses, compulsory courses and elective courses, explicit courses and implicit courses, etc. the course system usually presents an "inverted pyramid" logical structure of "basic courses - professional basic courses Professional Courses". Such a structure only considers the vertical connection of single subject knowledge. However, the horizontal expansion of multi-disciplinary knowledge is not considered, which directly affects the progressive and radiation effect of learners from the knowledge level to the ability and quality level. The reason why the university curriculum is developing in the direction of integration is not only influenced by the highly comprehensive development of contemporary science and technology, but also because the solution of major social production and life problems needs multi-disciplinary research. Traditional university courses usually form two plates of "compulsory courses" and "Elective Courses". In the teaching process, they often pay more attention to compulsory courses and subject courses. The curriculum system based on subject courses often ignores the comprehensive courses and elective courses that are more valuable for learners' personality development and all-round development. At present, although the "comprehensive curriculum" is being widely accepted, its development and implementation are often affected by the problems of knowledge trivialization, teachers' knowledge and interdisciplinary teaching ability, school organizational structure, curriculum assessment and evaluation, etc. However, the curriculum and teaching reform based on interdisciplinary has become the general trend. How to overcome the traditional setting of university courses and reflect the trend and characteristics of interdisciplinary integration? Studies have shown that there are two common ways to set up interdisciplinary courses: one is to set up "Module Courses" in the basic courses and professional courses of the curriculum system. One is to re integrate the curriculum content around the curriculum objectives and set up an interdisciplinary "comprehensive curriculum". The socalled "Module Curriculum" is an optional component to meet the professional ability and professional quality required for talent training. Its organic composition can form a curriculum combination with relatively wide caliber and shared discipline background on the framework of discipline knowledge structure. The first mock exam is a cross disciplinary module, and the corresponding elective credit requirements are selected. As for interdisciplinary comprehensive courses, students are generally provided with freely selectable curriculum resources in natural sciences, social sciences, technical sciences, humanities and other disciplines. The curriculum has changed from the original "subject center" to the organic combination of "social center" and "individual center". The selection of course content and the organization of teaching activities also establish an effective connection between the logical order of disciplines, the level of students' psychological development and the order of solving social problems. There are many kinds of cross courses, which break the boundaries of disciplines, help students form an overall view of knowledge, make them understand the problems related to historical, social and scientific development, and improve students' ability to adapt to work, life and scientific research in the future. In addition, many universities have set up "theme Courses", which is a new form of courses. The curriculum "theme" goes beyond the broad existing problems of the discipline, such as population problems and environmental problems, and allows learners to learn according to experience and situation [6].

\subsection{Curriculum Reform: From "Isolation" of Knowledge to "Integration" of Knowledge}

In the traditional sense, the curriculum is a subject centered curriculum. This "subject based" curriculum often pays too 
much attention to the subject ownership and logical system of knowledge, pursues academic standards and professional specifications, and pays attention to the characteristics of the curriculum, such as scientificity, systematicness and coherence. However, there are objective defects that the sub subject courses are closed and delimited, It is easy to ignore the integrity of scientific knowledge system and the overall characteristics of human beings. Generally speaking, scientific and reasonable knowledge structure should be three-dimensional, with the characteristics of comprehensiveness, practicality and openness. The rational knowledge structure of college students should be composed of basic knowledge, professional knowledge and related subject knowledge. With the cross integration of disciplines, in terms of knowledge inheritance, the university must organize the related discipline knowledge together to form a new curriculum organization. According to the differences in the training orientation of different students and the differences in students' individual characteristics and interests, the university must design and plan the professional training scheme, taking into account the professionalism, cross, comprehensiveness and universality. Through the setting of interdisciplinary courses and the organization of teaching, it can form a knowledge network structure with professional knowledge as the axis and outward reflection, so as to meet the requirements of education in the era of knowledge economy. Wang Dingding, a scholar, puts forward that interdisciplinary talent training is based on the "curriculum package" -- different knowledge modules run through one core problem as a whole, and taught by teachers who study the knowledge of each subject separately but have teaching ability. This interdisciplinary "Curriculum" should go beyond the discipline center. The purpose of its setting is to cultivate students to form a unique knowledge vision and thinking mode across the discipline boundary, and receive broader and richer general education. Teachers should not pay attention to whether students skillfully memorize some knowledge of a chapter or a section, but should pay attention to whether students are familiar with the potential links between various knowledge modules and whether they master the possible problem-solving path. Consciously carry out leaping knowledge transfer to enable students to complete the "series" and connection of knowledge points, which can better inspire students' thirst for knowledge and self-study ability than systematically introducing existing knowledge in class. For the educated, through the study of interdisciplinary courses, promote the integration of students' learning, form an overall view of knowledge and life, and cultivate students' ability to compare different disciplines and theoretical views, and master the ability to understand and synthesize. This kind of cultivation of compound and innovative knowledge emphasizes the intersection of disciplines. Through the integration of knowledge, the final goal is to shape students into innovative talents with compound knowledge structure. Interdisciplinary curriculum includes at least three different forms. The first is "integration" curriculum, which reflects the trend of integration differentiation integration of scientific knowledge and integrates the knowledge of different disciplines into a new knowledge system. The second is "compound curriculum". Combine more than two subjects (usually the intersection of Arts and Science) into one course; the third is "Relevance curriculum" draws some common concepts and principles from different disciplines to form an interdisciplinary curriculum. From the isolation of knowledge to the integration of knowledge, the purpose of curriculum construction is to enable students to have a clear understanding of the unity of knowledge life, liberate students' thoughts from a narrow disciplinary perspective, and improve their awareness, quality and ability to engage in knowledge innovation Capability [7].

\subsection{Curriculum System: From "Single Subject Knowledge Transfer" to "Multi- Disciplinary Knowledge Construction"}

By summarizing the relevant literature of humanities, social sciences and natural sciences, American scholar Klein pointed out that there are three representative schemes for the design of interdisciplinary curriculum system in Colleges and Universities: curriculum design associated with general education; Curriculum design related to subject groups; Curriculum design associated with research-based learning.

\subsubsection{Curriculum Design Related to General Education}

Interdisciplinary talent training courses in Colleges and universities are mainly undergraduate general education courses and liberal education courses. The former pays more attention to cultivating people from the perspective of outlook on life, while the latter pays more attention to cultivating popularity from the perspective of epistemology. It can be said that the correlation between general courses and the universality, diversity and integrity of curriculum knowledge promote students to get a sound and balanced whole person education. Through the integrated learning of humanities, society and natural sciences, students' cultural synaesthesia, scientific spirit and critical thinking are cultivated, which helps students form independent personality and correct values, have clear and clear expression ability and comprehensive and complete judgment ability, and realize the integration of knowledge, emotion and meaning [8].

\subsubsection{Curriculum Design Associated with Discipline Group}

The discipline group of a university refers to the discipline group formed by the combination of several related disciplines around a common field in a certain form. Generally speaking, discipline group is a multi-disciplinary and interdisciplinary combination with related discipline foundation and close internal relationship. Its framework is composed of main disciplines - supporting disciplines related disciplines. From the perspective of talent training, discipline groups generally have the following characteristics: first, the cross permeability between disciplines; Second, the complementarity of academic team members; Third, the research content is forward-looking; Fourth, the dynamics of discipline construction. Discipline group is not a simple collection of multiple disciplines, but follows the principle of "symbiosis" and uses multidisciplinary theories and methods to explore ways to solve major problems. The main disciplines often have the functions of cohesion and projection. At the same time, in the discipline group, the carrier for information exchange is the academic team, which is generally composed of discipline leaders and relevant researchers. They often carry out research and teaching on major social problems, scientific and technological problems or teaching and research projects at a certain stage, which is highly forward-looking and dynamic. The establishment of interdisciplinary talent training mechanism is not the concept of primary discipline and specialty, but the concept of discipline group and specialty group. The teaching courses 
are organized by these subject groups and professional groups to promote the cultivation of interdisciplinary talents. Grasping the discipline attribute of discipline group is the key to interdisciplinary curriculum design. As an interdisciplinary combination, the disciplines in the discipline group not only have a common discipline theoretical basis, but also reflect the relevance of discipline knowledge. The principle of curriculum design of subject group generally needs to form the network knowledge structure between interdisciplinary courses from the integrity of interdisciplinary knowledge; Coordinate the internal relations of various disciplines, give play to the leading role of core discipline courses, and realize the overall optimization of interdisciplinary courses. Basic theory and applied research courses are generally set at the upstream of the discipline, and applied technology courses in line with industry are generally set at the downstream of the discipline. In addition to paying attention to the combination of science and engineering and the infiltration of arts and science, the curriculum of the combination of art and engineering has also become a necessary link in the cultivation of interdisciplinary talents. Of course, in addition to the cross-border integration between discipline groups, financial colleges and universities can also actively break the gap between discipline groups and industry, take the development path of combining "production, learning, research and application", combine the basic and applied disciplines, and adopt various forms such as intra school collaboration, inter school collaboration and school enterprise collaboration to realize the integration of discipline basic theory courses and enterprise oriented Organic integration of social applied research courses.

\subsubsection{Curriculum Design Associated with Research- based Learning}

With the advent of the knowledge society, new knowledge is proliferating and constantly updating. School knowledge has been engaged in practical knowledge, gradually transformed into methodological knowledge, and began to occupy a dominant position. It not only reflects the knowledge connotation of thinking, judgment and problemsolving, but also a good way to cultivate learners to maintain long-term learning motivation and guide lifelong learning. Research-based learning is an innovative learning method based on knowledge innovation and research projects. It is generally distributed in interdisciplinary fields. It emphasizes the integration of teaching and learning, theory and practice, teaching and research. It takes projects or problems as the center and requires students to actively participate in the teaching process through the setting of interdisciplinary methodology courses and interdisciplinary research courses, Pay attention to the cultivation of students' innovative spirit and ability, and help learners constantly summarize and innovate new knowledge.

(1) Problem based curriculum design. At present, the most common problem in undergraduate education is the problem with good structure. Students can often obtain known and correct answers from clear problems and preferred solutions according to their knowledge. For students, this linear problem-solving process can only teach them a program of memory, practice and habituation, it overemphasizes the answer and ignores the generation of meaning. Although it is assumed that the skills acquired by solving "well structured" problems can be transferred to the solution of "complex and poorly structured" problems, problem-based learning research shows that this is not the case. When students try to use the effective strategies obtained by solving the problems in the "well structured" field to solve the problems in the "poorly structured" field, they will make excessive simplification, generalization and dependence on situation independent statements. Therefore, it is very important for students to solve the problem of poor structure in undergraduate education. However, problem-based learning often studies complex and ill structured problems. The establishment of interdisciplinary curriculum is to solve the problems that cannot be solved in a single discipline. In a sense, interdisciplinary curriculum is anti disciplinary; A successful interdisciplinary course usually starts and focuses on one topic, and then uses different disciplines to explore the topic. Traditional courses often make students think about specific problems with a clear scope, but problem-based learning is different from traditional curriculum based problems. The problems studied have a multifaceted structure and nature. In order to solve problems, individuals need the integration and integration of knowledge, skills and attitudes in multiple disciplines. This puts students in a real world problem-solving environment, so as to stimulate different thinking, learning and problem-solving modes, and promote the development of students' problem-solving skills. Because research questions in undergraduate education require students to spend a lot of time collecting data, selecting methods, establishing procedures from data collection, analyzing data and managing projects, the ideal place for research questions in the course is the experimental course.

(2) Research-based curriculum design. Attaching importance to discussion method and research-based learning are the two most remarkable characteristics in the teaching mode reform of foreign research universities. In addition to the way of projects or research topics, it creatively integrates research problems into the current classroom structure by designing interdisciplinary curriculum schemes, which not only provides students with interdisciplinary perspectives, but also establishes an interdisciplinary perspective The connection with knowledge units can also cultivate students' ability to deeply understand knowledge, think and act independently, which has become an important way to cultivate students' knowledge integration and interdisciplinary thinking. Research experience enables students to continuously check and re evaluate goals, objectives, procedures, data collection and analysis, solution paths, etc. This dynamic learning environment brings challenges to students, but it also enables them to learn important problem-solving skills in a multidisciplinary and interdisciplinary learning environment.

\subsection{4. "Curriculum" Setting: From "Systematic" to "Open"}

Curriculum is the organizational form of knowledge. From the process of knowledge development, it can be seen that at present, the knowledge form has developed from the traditional "scientific knowledge type" to the ongoing "postmodern knowledge type", which correspondingly affects the development trend of university curriculum and teaching. The traditional university curriculum and teaching are more specialized education in the early stage of the development of higher education. This specialized education attaches importance to the theory and integrity of the discipline itself. The characteristics of the curriculum are generally systematic, abstract and general, but such a curriculum is lack of flexibility and can not meet the requirements of different students and different professional directions. In order to 
realize the effectiveness of classroom teaching, we must realize the transformation of teaching content system from rigidity to elasticity. At present, in the interdisciplinary curriculum, we should gather the new advantages of talent training with an open and inclusive attitude. It is embodied in: paying more attention to innovation, highlighting the cultivation of students' innovative spirit, practical ability and sense of social responsibility; Pay more attention to comprehensiveness, pay attention to the learning and accumulation of basic theories and the formation of students' compound knowledge structure, highlight students' all-round development and improve their ability to adapt to social changes. Pay more attention to inclusiveness, adhere to multicultural views, cultivate students' ability to comprehensively analyze problems with different views and methods, and cultivate students' international vision; Pay more attention to selectivity, not stick to the systematicness of curriculum, highlight flexibility, diversity, openness and cooperation, and cultivate students to be able to apply research methods in multiple professional fields, etc. The emergence of "large-scale online open courses (Muke)" has broken the "wall" of the University and made the University borderless. It will undoubtedly trigger a new "Learning Revolution" and bring profound changes to the talent training and teaching methods of the University Under the mode, instructors and learners distributed all over the world are connected through a common topic or theme, and university courses, classroom teaching, student learning process, student learning experience, teacher-student interaction process, etc. are completely and systematically realized online. Turn the classroom from teacher centered to student-centered; Promoting teachers' Reflection on teaching and the exploration and research of teaching mode will help to promote teachers' role from a lecturer and interpreter to a real motivator and enlightener of learning, and learning will become more effective.

\subsection{Curriculum Resources: Integration of Teaching Resources from "School Level" to "Department Level"}

The core of realizing the goal of talent training lies in the scientific design and reasonable arrangement of the curriculum system. In terms of interdisciplinary and integrated talent training, the integration and development of interdisciplinary curriculum resources is the key. Specifically, a interdisciplinary and integrated curriculum system can be constructed from three levels: school level, department and research direction.

\subsubsection{Reorganize the School Curriculum Structure at the School Level}

The training of interdisciplinary talents requires the adjustment and optimization of curriculum structure. On the one hand, the school should pay attention to the integration and development of interdisciplinary curriculum resources, and emphasize the cross integration of courses in different disciplines, including the integration of Arts and science, science and engineering, the cross combination between traditional engineering disciplines, and the extension of traditional science to engineering education, so as to truly break the disciplinary barriers and professional barriers, and implement the whole process of interdisciplinary cross integration talent training. On the other hand, the school should also pay attention to the optimization of curriculum structure and the development of modular curriculum, build a curriculum system compatible with "general education curriculum module + discipline basic curriculum module + professional core curriculum module + internship practice curriculum module + personalized curriculum module", and promote the cluster development of curriculum in each training stage, Promote the effective link and cross integration of courses in different disciplines and professional fields with modular curriculum structure.

\subsubsection{Set Modular Courses + Professional Characteristic Courses at the College and Department Level}

The improvement of interdisciplinary integration level benefits from the modular design and comprehensive development of subject group courses. Modularization is the basic requirement of the construction of modern curriculum system. It has strong adaptability, flexibility and practicability because the goal of each curriculum module is clear and easy to realize. Modular curriculum design requires the first mock exam to decompose the whole goal of talent training into several interconnected sub goals in the design process of interdisciplinary talents training objectives. With the scientific design of modular courses, the professional boundaries of disciplines are broken, and the courses of different disciplines are reorganized in the same module with a certain logic. In addition, colleges and departments should also expand the scope and coverage of modular courses, reduce the proportion of professional compulsory courses, expand the selection range of professional elective courses, limited courses and optional courses, provide students with a variety of possible interests and career development choices, and meet students' personalized development needs.

The open, integrated, diversified and practical characteristics of interdisciplinary integration determine the diversification of its research direction or research field. On the one hand, the characteristics of interdisciplinary integration in Colleges and universities are insufficient; On the other hand, the creation of discipline and professional characteristics is not overnight, which needs continuous exploration and integration. At the same time, the lack of discipline and professional characteristics also shows that the research fields of discipline teams are not concentrated and focused enough. This limits the characteristic courses in the research field to a great extent (Group) development breadth and depth. Therefore, in terms of scientific positioning and characteristic refinement of research direction, we should focus on deep cultivation in 3 - 4 fields according to the school running tradition and the research direction of teaching staff, and constantly explore and integrate in the process of research, so as to transform the latest research results and research frontier dynamics into courses (Group) and make it serve the cultivation of interdisciplinary and integrated talents in colleges and universities.

\section{References}

[1] Xu Dunhui. Research on talent training of new engineering from the perspective of interdisciplinary [D]. Nanjing University of Posts and Telecommunications, 2019.

[2] Yuan Guanglin. Organization construction and system design of comprehensive interdisciplinary development -- Based on the thinking of establishing world-class discipline in Chinese universities [J]. Degree and graduate education, 2018(07):1-8.

[3] Li Bo. Multidimensional research on the evolution of physical education knowledge in China from the perspective of interdisciplinary [D]. Fujian Normal University, 2018. 
[4] Gu Peihua. New engineering and new paradigm: practical exploration and thinking $[\mathrm{J}]$. Research on higher engineering education, 2020(04):1-19.

[5] Lin Jian. Deeply and solidly promote the construction of new engineering -- organization and implementation of new engineering research and practice projects $[\mathrm{J}]$. Research on higher engineering education, 2017(05):18-31.
[6] Bai Qiang. Innovation of university knowledge production mode and discipline construction $[\mathrm{J}]$ University education science, 2020(03):31-38

[7] Ye Yingping, Lu Yanqiu, Xiao Yanhong. Construction of knowledge innovation model based on network embedding $[\mathrm{J}]$. Library and information work, 2017,61(07):102-110.

[8] Zhang Delu, Wu Lianchun. Exploration on the integration mode and teaching mode of interdisciplinary knowledge $[\mathrm{J}]$. Chinese foreign languages, 2021,18(01):45-52. 